\title{
Artificial Intelligence in an Age of Digital Globalization
}

\author{
Irina V. Alyoshina \\ Department of Marketing \\ State University of Management \\ Moscow, Russia ialyoshina@gmail.com
}

\begin{abstract}
Artificial intelligence (AI) is regarded to as the key element of digital globalization and of Globalization 4.0. Social consequences of AI advancement and their meaning for Russia's education digital transformation are revealed.

Keywords: artificial intelligence, digital globalization, Globalization 4.0, digitization, digital platformization, higher education.

\section{DIGITAL GLOBALIZATION AS THE STAGE OF ECONOMIC GLOBALIZATION'S EVOLUTION}

Digital globalization is the contemporary stage of globalization processes, characterized by rapidly growing cross-border flows of ideas, information and innovations as a result of the replacement trend in the 21 st century of physical chains of production and trade on global information networks [1]. It appeared in 2014 and was described by McKinsey Global Institute [2].
\end{abstract}

Artificial Intelligence (AI) is the key technology for the last stage of globalization (Table 1). It plays important role for further expansion of digitization of global economy and so influences socio-economic changes across the globe.

$\mathrm{AI}$ is defined in different ways, depending on the context of research. Association for the Advancement of Artificial Intelligence sees AI as "the scientific understanding of the mechanisms underlying thought and intelligent behavior and their embodiment in machines." [6]. The more applied approach is: "software technologies that make a computer or robot perform equal to or better than normal human computational ability in accuracy, capacity, and speed" [7]. At the same time AI can be regarded to as a "collection of interrelated technologies used to solve problems that would otherwise require human cognition" [8]. Machine Learning (ML), natural language processing (NLP), speech recognition, computer vision and automated reasoning - can be seen as basic methods, or technologies, of AI. AI technologies solve the problems of recognition and generation of objects (images, texts, sound, events and others) [1].

The developments in economy and social life are influenced by AI advancement. The productivity and efficiency of manufacturing, transportation and energetic systems depends on AI technologies, supporting complex resource management; schedules, traffic, equipment and capacity loading education, healthcare, communications effectiveness are also dependent on speed and quality of big data processing and individual targeting of personal needs for millions and billions of people around the world.

$\mathrm{AI}$ is seen by national governments of the leading countries as the means of resolving economic and social tasks of the 21 st century and at the same time as the sphere of global risk because of uncontrolled development and possible improper use of AI technologies. In 2017 the governments and industries of Canada, Japan, Singapore, China, Australia, Finland, and UAE declared AI initiatives. In 2018 Taiwan, Denmark, France, Italy, Great Britain, EU, US, Sweden, Australia, Mexico, Germany followed the suit. AI is one of the basic technologies of the Russia's National Technological Initiative, - the government-led program for supporting Russian companies' leadership in high-tech global markets.

US is the world leader in AI research. American companies - Alphabet (Google), Amazon, Apple, Facebook, IBM and Microsoft are the largest technological players in AI. In 2016 the national AI strategy, - "The National Artificial Intelligence Research and Development Strategic Plan" was issued in US. 
Table 1. Digital Globalization stage in the process of globalization evolution (adapted from $[3 ; 4 ; 5]$ )

\begin{tabular}{|c|c|c|c|c|c|}
\hline $\begin{array}{l}\text { Globalization- } \\
\text { Era/ stage }\end{array}$ & $\begin{array}{l}\text { Leading } \\
\text { Exports }\end{array}$ & $\begin{array}{l}\text { Leading } \\
\text { Nations }\end{array}$ & $\begin{array}{c}\text { Enabling Tech- } \\
\text { no-Era for } \\
\text { Globalization Era }\end{array}$ & $\begin{array}{c}\text { Enabling } \\
\text { innovations }\end{array}$ & $\begin{array}{c}\text { Titans of } \\
\text { Globalization } \\
\text { Era }\end{array}$ \\
\hline $\begin{array}{l}\text { Globalization } 1.0 \\
\text { / 1900-1914 }\end{array}$ & $\begin{array}{l}\text { Textile, Industri- } \\
\text { al goods }\end{array}$ & $\begin{array}{l}\text { Great } \\
\text { Britain }\end{array}$ & $\begin{array}{l}\text { 1-st Industrial Rev- } \\
\text { olution (1780-s } \\
\text { - middle of } 19 \text {-th } \\
\text { century) }\end{array}$ & $\begin{array}{l}\text { Steam en- } \\
\text { gine, steam } \\
\text { trains and } \\
\text { ships }\end{array}$ & $\begin{array}{l}\text { Railroad } \\
\text { companies }\end{array}$ \\
\hline $\begin{array}{l}\text { Globalization } 2.0 \\
\text { / 1945-1989 }\end{array}$ & Factories & US, USSR & $\begin{array}{l}\text { 2-nd Industrial } \\
\text { Revolution } \\
(1870 \mathrm{~s}-1910 \mathrm{~s})\end{array}$ & $\begin{array}{l}\text { Assembly } \\
\text { line, automo- } \\
\text { bile, airplane }\end{array}$ & $\begin{array}{l}\text { Ford, Exxon } \\
\text { Mobil, } \\
\text { GM }\end{array}$ \\
\hline $\begin{array}{l}\text { Globalization } 3.0 \\
\text { / 1989-2008 }\end{array}$ & $\begin{array}{l}\text { Global Supply } \\
\text { Chains }\end{array}$ & US & $\begin{array}{l}\text { 3-rd Industrial } \\
\text { Revolution } \\
(1960 \mathrm{~s}-1990 \mathrm{~s})\end{array}$ & $\begin{array}{l}\text { Computer, } \\
\text { Internet }\end{array}$ & $\begin{array}{l}\text { IBM, HP, Dell, } \\
\text { Microsoft }\end{array}$ \\
\hline $\begin{array}{l}\text { Globalization } 4,0 / \\
2008+ \\
\text { Digital } \\
\text { Globalization } \\
2014+\end{array}$ & $\begin{array}{l}\text { Digital Goods/ } \\
\text { Services /// } \\
\text { Data, } \\
\text { Information }\end{array}$ & US, China & $\begin{array}{l}\text { 4-th Industrial } \\
\text { Revolution } \\
(2000-2010-\mathrm{s})\end{array}$ & $\begin{array}{l}\text { Robotization, } \\
\text { Artificial In- } \\
\text { telligence, } \\
\text { autonomous } \\
\text { vehicles, } \\
\text { Internet of } \\
\text { Things }\end{array}$ & $\begin{array}{l}\text { Google } \\
\text { (Alphabet), } \\
\text { Facebook, } \\
\text { Amazon, } \\
\text { Tencent }\end{array}$ \\
\hline
\end{tabular}

China, the UK, France and the EU are also the major players in AI development. Chinese companies, - Huawei, Alibaba, Tencent, Baidu, are acknowledged leaders in the world markets of applied AI technologies.

AI technologies are at the core of global digitization, enabling the global scale of big data processing. Physical goods' production and trade, common for previous industrial revolutions and stages of globalization, is replaced with global information flows. So, the competitiveness in the global economy depends more and more on the ability to generate ideas and innovations, to digitalize and robotize. Digital innovations intensify competition within national markets of products; services, capital and labor, and it also increase international and global competition.

Digitization and virtualization, keeping data in cyberspace, create technological infrastructure for digital economy. Digital online platforms often perform as vertically integrated systems, cutting out traditional intermediaries, - agents and offline resellers, marketing agencies. AI ensures functioning of "smart" systems, - analytical, predictive and prescriptive in manufacturing, transportation, healthcare, science and education, communications and trade.

The leading global players of previous industrial revolutions, - railroads, automakers, oil, gas and food companies and even airlines are loosing their top positions in global ratings of sales, capitalization and brand equity. The reason is that the scale of their operations is limited by nature and physical environment, or natural limits (geography, climate, natural resources) or by laws [9]. In the era of Globalization 4.0 old economies of scale have been replaced by limitless network effects of global digital platforms. For Facebook, Google, Amazon the upper user limit is the entire global population. The rate of increasing the number of users for these companies exceeds the rate of expanding for brick-sand-mortar companies. Four big IT companies already count more than a billion users: Alphabet, Facebook, Microsoft (US) and Chinese Tencent. Global scale of operations for Digital conglomerates transcend traditional business and influence social environment globally.

IT-sector wins while building mass-use technological platforms. However, employment situation is getting worse for low- and middle-skills jobs. Industrial companies do not need as much labor as decades ago because of digitalization, automation and robotization. The demand for workforce is becoming polarized - high skilled and high paid or low-skilled and low-paid people have more chances to be employed. That is the reason for decreasing middle-class, growing inequity 
and social tensions in advanced economies. The gap between the winners and the losers of the Fourth Industrial Revolution is widening.

Fourth Industrial Revolution means not only digitization of industries and economy, but also changes in social and of political spheres. Digitization fundamentally transforms global, regional, national and local economies, and also businesses, communities and politics. The divide between occasionally and temporarily employed, the precariat, and the privileged elite, increases. Traditional industries have already been restructured (paper publishing, mass media, off-line education, retailing) and disrupted by digital economy deployment, millions of workers lost their jobs. Growing inequity and instability of jobs, downsizing middle class, migration rise concerns and protests even in the most developed countries.

The first three stages of globalization, - Globalization 1.0, Globalization 2.0, Globalization 3.0 (Table 1), - affected basically material goods production and jobs in manufacturing, and so basically blue collar workers in advanced economies. AI is expected to replace not only the routine tasks and jobs bus also the middle-skills and even high-skills, expert position. So, Globalization 4.0 is of a serious concern for services' sector and professionals. Digital technologies make cross-border movement of professional jobs far more easy and possible than previously. Coding, web-design, project management, research, internet-marketing, copywriting, consulting, editing are the activities movable online, abroad and off-shoreable. So, Globalization 4.0 exposes not only working and middle class, but also upper-middle class of developed countries to the global opportunities and challenges and so confronts even developed countries' societies with growing global competition.

Globalization 4.0 makes competition for increasing number of resources global. Natural resources, labor, and capital are added with ideas, brains and innovations. Therefore, the AIrace makes real sense for ensuring global competitiveness for nations, industries, cities, companies, organizations and individuals.

\section{AI HIERARCHY OF NEEDS; RUSSIA IN THE CONTEXT OF DIGITAL GLOBALIZATION}

AI technologies seem to be very attractive for increasing efficiency and effectiveness of business, industries and economies. Many market players would like to use AI. However, there are specific prerequisites for AI adoption (Fig. 1).

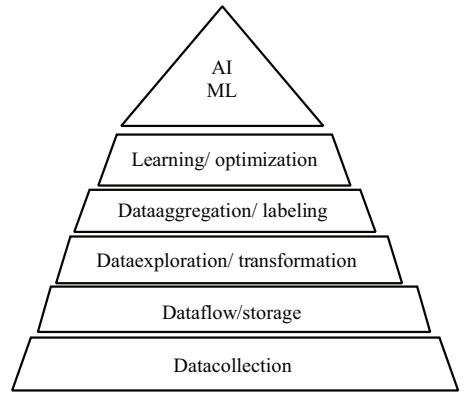

Fig. 1. AI hierarchy of needs (adopted from [10])

The basic question for potential users is "How AI could help us to perform our tasks and to achieve our goals?" However, organizations often are not ready for AI because of absence of infrastructure to implement even basic data science algorithms. Analog of Maslow's hierarchy of needs for AI can be used to illustrate the prerequisites important for AI technologies implementation. Before one could use AI, Machine Learning (ML) is needed. ML means a training data already prepared, being processed before. And in order to have data for processing, data collection 
system is needed - sensors or other receiving facilities. Data received needs channels to flow and storage spaces already at place.

Russia's specific for AI technologies is that the largest territory in the world is not covered yet with IT infrastructure, necessary for intensive and expanded data collection. Digitization of operations and business-processes is limited because of absence of expanded and reliable IT infrastructure, especially out of cities, in rural regions of Russia, where more than the third of Russians lives permanently or temporarily during the year, because of seasonal and pendulum migration. So, the basis of pyramid is not ready yet for massive AI technologies usage. Internet-access penetration is relatively higher for urban territories and large cities, but it is still low in rural regions. Rural regions underrepresentation in data sets and so in training data for machine learning means incomplete information and potential biases of algorithms and AI systems.

There is already global competition for customers' data. Global IT giants work hard to attract citizens all over the world to use their services in exchange for users' attention and data. Free social media, video and e-mail services are exchanged for data, one of the most valuable resource for digital economy. Russian IT companies are far not the leading players even in home country market, that means they are limited in data collection abilities and so, in possibilities of ML and AI technologies.

EU, China, Russia try to limit data collection activities for foreign player at their territories. However none of Russian IT companies are able to achieve global network effect comparable with Facebook or Google. At the same time closing national data borders means cutting the country off from contemporary technologies of communication, information and learning and that is why may be not the best decision. So, the audience education about benefits and risks of global digitization may be the optimal choice for the strategy of AI deployment in Russia.

At the same time, AI technologies implementation needs the specific context, or culture and environment to succeed. Innovations are not only about inventions, according to MIT professor Loren Graham [11]. He pointed out that the intention to get innovations without having adequate social-economic environment means the same as the intention to get milk without cow.

Therefore, the problem of AI technologies in Russia seems to be not only technical in its nature but far more complex; it is also social, cultural and demands multidisciplinary approach to be resolved. Wide circles of human and social sciences' experts need to be attracted for public and professional discourse on $\mathrm{AI}$ and innovations as a whole.

\section{AI FOR HIGHER EDUCATION: GLOBAL/NATIONAL PERSPECTIVE}

Digitization of global economy means dematerialization of production and so the increasing knowledge intensity of global value chains. Growing speed of technological changes transforms industries constantly and quickly. High speed of changes and high level of uncertainty demand new model of education. The key feature of 21-st century's education are supposed to be:

1. individualization of learning programs, personalization, student-centricity,

2. just-in-time approach for already employed,

3. learning "on the go", while working,

4. flexibility, mobility, adaptability, accessibility,

5. real-world approach with global and international, but not only nationally-oriented vision.

The majority of these features is impossible to achieve without automation, digitization and AI technologies already used by global IT platforms. Educational systems are already under pressure of digital transformation, global competition and of digital platformization. But in fact no one nation, government or university in the world and no one of University professors today is able alone to keep in pace with technological changes simply because none of the national governments or Universities or individuals have the technological capacities for information gathering, processing and distribution as global tech giants have, - Facebook, Google or Amazon. And that is why education often lags behind the realities and challenges of the world. 
At the same time none of this tech giants own even small part of the knowledge of the world and that is why is unable to become "global university" alone. So the future of education is seen as global network cooperation between tech giants and knowledge workers, practical specialists and scientists. This initiative supposed to be global and tech giants may serve as technical platforms for global knowledge sharing, using AI technologies. In fact it is in part already in place, however some more job is needed to be done to make system more appropriate and useful for the wide range of culturally, demographically and intellectually diverse audiences of the world. Traditional universities and academics, supported by industries, national governments, international organizations and individuals, can do part of this job (helping in concept and business-model development; knowledge systematization, adaptation, localization, verification).

Could there be globally competitive national-oriented higher education in an age of digital globalization? And to what degree higher education today may be globally, internationally or nationally-oriented? Questions of national identity, specifics and independence are quite discussible for many countries and social groups. However, the answer means that the choice for the fortunes of the future for upcoming generation. That is why the decision needs to be made not only by national governments but also by individuals, employers and other stakeholders of the future.

\section{REFERENCES}

[1]. Alyoshina I.V. Artificial-Intelligence Marketing in an Age of Digital Globalization, in Proceedings of the 23-th International Scientific-Practical Conference "Actual Problems of Management - 2018”. Moscow: State University of Management, 2019, pp. 206-209. (In Russian). Available at: https://www.elibrary.ru/item.asp?id=37141929.

[2]. Manyika J., Lund S., Bughin J. et al. Digital Globalization: The New Era of Global Flows. Available at: https://www.mckinsey.com/ /media/McKinsey/Business\%20Functions/McKinsey\%20Digital/Our\%20Insights/Digital\%20globalization\%20The \%20new\%20era\%20 of $\% 20$ global\%20flows/MGI-Digital-globalizationExecutive-summary.ashx.

[3]. Vanham P. A brief history of globalization. Available at: https://www.weforum. org/agenda/2019/01/how-globalization-4-0-fitsinto-the-history-of-globalization/.

[4]. Alyoshina I.V. Globalization as a Factor for Managerial Systems' Market Orientation Evolution, 2019, unpublished. (In Russian).

[5]. Baldwin R. If this is Globalization 4.0, what were the other three? Available at: https://www. weforum.org/agenda/2018/12/if-this-isglobalization-4-0-what-were-the-other-three/.

[6]. Association for the Advancement of Artificial Intelligence (AAAI). Available at: https://aitopics.org/search.

[7]. Artificial Intelligence definition. Available at: https://www.businessdictionary.com/definition/artificialintelligence.html.

[8]. The Effective and Ethical Development of Artificial Intelligence. ALOCA, 2019. Available at: https://acola.org/wp-content/uploads/2019/07/hs4_artificial-intelligencereport.pdf?fbclid=IwAR12tfLo9SpIsvxIgEByUSo4KF1O4XA5FRAxk8_0QmVh8pFufDHqZLgbv8Y

[9]. Schwab K. Globalization 4.0. A new architecture for the Fourth Industrial Revolution. Available at: https://www.foreignaffairs.com/articles/world/2019-01-16/globalization40.

[10]. Rogati M. The AI hierarchy of needs. Available at: https://hackernoon. $\mathrm{com} /$ the-ai-hierarchy-of-needs- $18 \mathrm{f} 111 \mathrm{fcc} 007$.

[11]. Graham L. Why do Russian innovations fail? Available at: https://www.youtube. com/watch? $=$ MrWiP23Tlwk. 